\title{
Foundations, trusts and funds in near mine closure and post- closure environments: a case from Bolivia
}

\author{
V. Pacheco WorleyParsons Limited; and Centre for Social Responsibility in Mining, The University of \\ Queensland, Australia
}

\begin{abstract}
In the last three decades, an increasing number of mining and resources companies around the world have established community funds, trusts and foundations (FTFs) to comply with government legislation or as part of their social or philanthropic programmes. The growth of FTFs follows corporate social responsibility trends within the resources sector to improve the way in which economic benefits are distributed among stakeholders. Benefit sharing mechanisms such as FTFs offer strategic channels by which companies can mobilise resources to mine affected communities. FTFs vary in structure, approach and aims, with the more participatory models relying on community input into the decision making process and the implementation of community development projects (CSRM, 2009). The success or otherwise of FTFs is well documented in academic and industry circles. The degree of success of FTFs varies depending on factors such as company support and community approval. However, as most of the research occurs during the operational phase it does not seem to be appropriate to comment on their long-term success, except where they may already have failed in the short term. This approach does little to expand our understanding of FTF community empowerment and self-reliance in post closure environments. In other words, from the perspectives of community development and mine closure planning there is a case for documenting and evaluating FTFs operating at a time when company funds are no longer accessible and when management of the FTF requires considerable input from the community it was meant to serve. This paper provides baseline results from research undertaken on the Inti Raymi Foundation in Bolivia. It analyses the community engagement practices and the programs used by both the foundation and its parent company, Empresa Inti Raymi S.A. (EMIRSA) to facilitate the process of closure.
\end{abstract}

\section{Introduction}

In the last three decades, an increasing number of mining and resources companies around the world have established community funds, trusts and foundations (FTFs) to comply with government legislation or as part of their social or philanthropic programmes. According to a World Bank study, there were only five mine related FTFs active in the period 1950 to 1980 . From 1980 to 2008 this number had grown to 61 in the developing world and 20 in the developed world (World Bank, 2010a).

The growth of FTFs follows Corporate Social Responsibility (CSR) trends within the resources sector to improve the way in which economic benefits are distributed among stakeholders. Benefit sharing mechanisms such as FTFs offer strategic channels by which companies can mobilise resources to their relevant communities. Even though FTFs vary in structure, approach and aims, invariably, the more participatory FTF models rely on community input in the decision making process and the implementation of community development projects (CSRM, 2009).

The participatory model is important when planning for closure because communities become empowered by being involved in the process of determining their own future. This is particularly true in those cases when an FTF is established for the purpose of supporting a community through the process of closure and is expected to outlast mining operations. One of the risks associated with the participatory model, however, is that it is costly and time consuming and as such may not be appropriate in the cases of sudden or forced mine closure. 
This paper will explain how a mining company (and associated foundation) in Bolivia, with a modest budget, has been able to achieve relative success in terms of engaging with its affected communities on issues relating to a) the eventual closure of the mine and b) the establishment of three community funds for the benefit of the mine's affected communities.

The paper is divided into four parts: Part one consists of a review of the academic and industry literature on closure planning, mining foundations, funds and trusts and FTF sustainability; Part two of the paper describes the methodology used for this study; Part three is a discussion of the history and context of the case study and Part four analyses the results of the research.

\section{$1.1 \quad$ Closure planning}

Most literature on mine closure focuses on the technical aspects of site decommissioning and environmental remediation and rehabilitation. This reflects a 20 -year trend from the 1970 s when the main focus of closure plans was environmental issues (Laurence, 2006), limiting the socio-economic aspects of closure to environmental liabilities (Finucane and Santini, 2010; Rose and Morgan, 2010). However, in the last decade or so, an increased mining industry focus, first on sustainable development and more recently on CSR, has resulted in growing recognition of the socio-economic impacts of mine closure on communities and the need to address these impacts through the closure planning process (Rose and Morgan, 2010).

As a result of this recognition, the term 'integrated mine closure' has now become more common in the vocabulary of industry practitioners, academics and policy makers. Whereas the term originally referred to the integration of closure considerations into an operation's lifecycle, it currently encompasses the integration of social and environmental considerations into the closure planning process (ICMM, 2006).

Literature that takes into consideration social and environmental considerations invariably says that best practice requires that closure planning be built into the mine cycle and begin at the inception of mine feasibility. In other words, financial and community development instruments need to be in place to ensure sufficient resources and know-how exist at the end of the mine's life to implement closure plans (Warhurst et al., 2000).

The shift from a narrow technical focus to a broader and more inclusive view of mine closure is occurring at a time when the private, government and civil society sectors perceive mining not just as an enclave type economic activity but as an activity that has the potential to be fully integrated into local economies. As mining operations provide the only significant mainstream economic activity in many remote and regional areas, particularly in developing countries, mine closure can have serious detrimental political and economic effects on communities. The sudden closure of tin mining in Bolivia, coal mining in parts of the former Soviet Union, and retrenchments in the South African gold industry are all examples of mine closures that affected the economy of entire regions (DRET 2009; World Bank and International Finance Corporation, 2002; IIED and WBCSD, 2002). For this reason, in an increasing number of cases, mine closure planning includes avenues for the transition to a post-mining economy. In the best cases it relies on a trilateral process of consultation and problem solving that involves mining companies, governments, and communities (Stacey et al., 2010; World Bank and International Finance Corporation, 2002).

Despite these conceptual advances closure planners face a number of challenges including lack of capacity in the community, unwillingness of stakeholders to collaborate with each other, lack of strong governance systems and economic dependence on mining activity, among others. For instance, mining companies have conventionally contributed, directly or through mining FTFs, to community development activities by investing in infrastructure or by sponsoring community services, such as health and education programs (ICMM, 2005). In many cases this infrastructure is donated to the surrounding communities upon mine closure. However, a clear theme that emerged from a mine closure workshop hosted by the World Bank Group in 2000 was the difficulty of maintaining and sustaining community assets and social services postmining, particularly in weak governmental contexts (Finucane and Santini, 2010; IIED and WBCSD, 2002; Jackson, 2002). 
According to the ICMM (2005), infrastructure and services have often deteriorated once the company withdraws its financial support because projects or programs:

- were chosen by the mining company employees and/or the local elites acting in their own accord

- were built or run by outsiders, with little management involvement from local community members

- were only accessible by the more affluent members of the community and not by the poorer members

- did not respond to the needs of those the development program was meant to serve

- required technology or knowledge not locally available to maintain them

- the capacity of local people to manage the programs was not built up to a sufficient level.

All of these factors point to a lack of effective community and other stakeholder participation in the design of development projects for mine affected communities. Stakeholder participation, along with a strategic approach to community investment (ICMM, 2005; IFC, 2010), the formation of multi-stakeholder partnerships (Davy, 2000; ICMM, 2010) and a focus on capacity building (ICMM, 2005; IFC, 2010; IIED and WBCSD, 2002) should all be important elements of sustainable community development and mine closure planning.

\subsection{FTF purpose, organisation and definition of mining FTFs}

The integration of social and environmental considerations into the closure planning process has resulted in mining companies relying on an increasing number and type of approaches to minimise negative impacts and to increase the chances of leaving positive legacies for project affected communities. These approaches, designed to respond to philanthropic interests, or to comply with government regulation or as part of CSR imperatives, include benefit-sharing mechanisms such as treaties, community development projects, direct donations and FTFs. Of these, the latter are increasingly being used as effective ways of channelling mining benefits to the community. According to the World Bank (2010a) there are three main purposes for which the mining sector uses FTFs:

1. Community investment - voluntary actions or contributions by companies that go beyond the scope of normal business operations and are intended to benefit local communities in project affected areas.

2. Compensation - payments made by companies to mitigate the social and environmental impacts generated by projects, including direct cash compensation to individuals (e.g. landowners) and financing for development projects at the community level over an extended period of time.

3. Government payments - taxes and royalties as well as other payment schemes, including voluntary contributions that exist between mining companies and various levels of government, which are intended for redistribution to communities through different benefit sharing mechanisms.

The purpose for the establishment of these entities will determine, in great measure, their organisational attributes. These attributes, in turn, vary according to the legal and regulatory frameworks of the jurisdictions in which they are incorporated, including elements such as permissible economic activity, provisions for supervision, management, accountability and auditing, tax status and provisions for amendment or dissolution. The political economy in which FTFs are established also greatly impacts their specific characteristics. For example, in 2007, 40 companies and the Peruvian Government signed an agreement to make a voluntary contribution (Aporte Voluntario) to local and regional funds for the poorest provinces and regions of Peru. The payment addressed perceived inequities, emerging from rising commodity prices, between project revenues and anticipated royalty and tax benefits. The agreement included company commitments to good management of these funds to help circumvent bureaucratic 
difficulties in disbursement and management of royalties to provinces and municipalities (World Bank, 2010a). Similarly, in Papua New Guinea, land rights agreements have included the creation of trust funds for development purposes. The Papua New Guinea Sustainable Development Program was created as part of a divestiture agreement with the PNG Government (Warhurst, 2002).

These outside influences affect the way the FTFs express their purpose and also their community. According to Hamann et al. (2001), the organisational culture of FTF may diminish community dependence on a company's presence in an area. In this way, FTFs can overcome some of the problems typically associated with other models of community development initiatives within companies, such as lack of motivation, conflict of interests, absence of institutional specialisation in community development and paternalism.

There is general inconsistency in the usage of the terms 'foundations', 'trusts' and 'funds' despite the increasing usage of FTFs as benefit sharing mechanisms. For example, the Anglo American Chairman's Fund and the Rössing Foundation are both legally incorporated as trusts (World Bank, 2010a).

According to the World Bank, trusts are employed in countries using common law and foundations are preferred in countries adhering to civil law. Trusts represent a legal relationship between the settler of assets, the trustee, and the beneficiaries, meaning that trustees have more specific responsibilities and liabilities. A 'fund' on the other hand, is a general term used to describe a mechanism that may be legally defined as a trust or foundation (or a company budget item). A 'foundation' generally applies to an institution used for charitable or family purposes and offers more flexibility than trusts or funds in terms of the activities they are able to undertake to fulfil their objective (World Bank, 2010a).

Two main types of foundation structures exist:

1. Company/corporate foundations - created by companies as separate legal entities with the purpose of delivering social development projects.

2. Community foundations - independent, philanthropic organisations working in specific geographic areas (e.g. a city, district or province), which primarily act as grant-making foundations through endowed funds from a broad range of private and public donors, primarily from inside the community. Multi-sectoral local boards commonly govern this type of foundation (Sera and Reynolds, 2008). The Inti Raymi Foundation falls within this category.

An important characteristic of community foundations is the fact that they aim to build an endowed fund, which supports their long-term sustainability (Sera and Reynolds, 2008). Whilst mining FTFs may structure their funding to include an endowment, this is not a necessary characteristic, particularly if the fund is created to deliver benefits while a mining project is operational. Also of note is that community foundations aim to pool funds created by donors from different sectors of the community, and include a board of directors that represent the public interest (Lowe, 2004). Mining FTFs, on the other hand, are typically funded by mining companies themselves and may or may not include multi-stakeholder bodies in their governance structures. However, the more successful foundations have been able to attract funding from external donors and have boards that represent a range of stakeholders (IIED and WBCSD, 2002).

An important question to raise at this point is whether the structure and purpose of FTFs have some bearing on the success of their programs? Even though there is no definitive answer to this question, there are certain elements that are common to successful FTFs.

\subsubsection{Common elements found in successful FTFs}

The success or otherwise of FTFs is well documented in academic and industry circles (Banks, 2003; Yakovleva and Alabaster, 2004; CSRM, 2005; Esteves and Vanclay, 2009; Barclay, 2010). Recent studies by the World Bank, the International Institute for Environment and Development (IIED) and the World Business Council for Sustainable Development (WBCSD) carried out in the area of FTF success found that best practice for mining FTFs include: 
- A clearly defined strategic vision, outlining the FTF's role as a development actor in the local environment. This also involves having a single purpose, i.e. the foundation will be primarily, a community investment, or a form of compensation or government transfer but not a combination of all these.

- Foundations and funds should be managed by an independent structure to ensure trust and institutional sustainability. At a minimum a board of directors, who are representative of the different stakeholder groups, should oversee the foundation.

- Incentive schemes must be established to retain high calibre staff and maintenance of an efficient administrative structure.

- Companies should ensure that their financial contributions to foundations are fixed, sufficient and transparent. Ideally, funding should not detract from government spending.

- In some jurisdictions companies have the choice to not contribute to government redistribution programs and instead use their own foundations, trusts, funds or infrastructure tax credits to distribute benefits to the community. Whatever choice is made must be communicated to company stakeholders and the community.

- High levels of co-financing. In the medium to long term, alternative financing mechanisms would strengthen the likelihood of the funds being sustained. Ideally, governments or NGOs should take primary responsibility.

- Delivery mechanisms should be designed in a way that bolsters rather than undermines government capacity.

- FTFs must carry out impact-based monitoring and evaluation of their projects and act accordingly.

- Effective community and stakeholder participation in decision-making and throughout all stages of the project is essential to the success of sponsored projects (IIED and WBCSD, 2002; World Bank, 2010b).

In the World Bank study, success was defined as the ability of FTFs to deliver results for communities in line with the International Finance Corporation's principles of community investment that "seeks to avoid dependency, encourage self-reliance, and create long-term benefits that can outlast company support" (IFC, 2010). The same study provides cases where, despite carrying out a number of best practice elements, FTF's desired outcomes were not achieved (World Bank 2010b). The reasons for these failures might be attributed to a combination of structural elements of the FTF, the type of engagement with the community and external factors that are beyond the FTF's control. For example, Utkal Aluminium International Limited's (UAIL) rural development trust was set up to counter planned displacement and local concerns over bauxite mining project outcomes. However, the trust was founded at a stage when animosities had already developed between the company and the community. In addition, while being nominally independent, the trust received all its income from UAIL and was governed by a UAIL-dominated board. Its close relationship to UAIL meant that the community viewed the trust as an agent of the company. In addition, the trust focused its consultations only on those who were displaced or had lost land rather than all those whose livelihoods were affected by the proposed development. These factors resulted in the inappropriate targeting of resources and compounded a view in the community that the trust was an 'act of tokenism' (Barney, 2003).

Some FTFs do, however, achieve positive outcomes for communities after adopting best practices. In a lot of cases this is a win-win for most stakeholders but sometimes success carries its own problems. In examining the role of FTFs in Papua New Guinea, Banks (2003) argues that the presence of effective FTFs in countries where the administrative capacity of the local or provincial government is low has the potential to further weaken the government. Bank's observation is not a criticism of effective FTFs but a commentary on the need to increase the capacity of all stakeholders when operating in regions with low levels of development. 
What is clear from these examples is that success must be measured against a set of development indicators. Even though the World Bank study provides success criteria for FTFs wishing to adhere to international community investment standards it does not provide a specific list of indicators to measure success.

\section{Methodology}

The literature on FTFs operating in near closure or post closure environments is scant. Studies on the effects of mine closure on communities abound but only a few of these analyse the role of FTFs during the process. For instance, Haney and Shkaratan's (2003) study on the impacts of coal mine closure on communities five years after closure in Romania, Russia and Ukraine provides policy recommendations for industrial restructuring in communities dominated by a single industry, emphasising the importance of capacity building. Jackson's (2002) analysis of mine closure in Papua New Guinea, also focuses on capacity building, using Ok Tedi, Misima, and Porgera as primary case studies. Other in-depth case studies include McGuire's (2003) analysis of the closure steering committee process of the Kelian gold mine in East Kalimantan Indonesia, which outlines the methodologies used to develop sustainable solutions to impacts in a context of limited governmental capacity; and Laurence's (2006) analysis of the reasons that mines close and corresponding closure risk model, which emphasises the importance of community engagement throughout a mine's operating life and particularly during the mine closure processes.

Research on FTFs is also abundant. However, a common methodology used in this type of research is to analyse FTF performance while the parent company is in the operational phase. This approach may seem appropriate given that company funds are most accessible by FTFs during this time but it does little to expand our understanding of FTF sustainability and community engagement and self-reliance in near closure or post closure environments.

In recognition of this problem, the World Bank's Mining Policy Division started a program of research in late 2009 to study "how mining foundations (but also trusts or funds) have been used as benefit sharing mechanisms and to which extent local or national governments are or should be involved" (C. Pelon, 1 Dec. 2010, written comm.) In 2010, the Division published an overview on the subject (World Bank, 2010a) and a series of case studies that included foundations established for the purposes of handling mine closure (World Bank, 2010b). The publication of these studies is a first step in generating knowledge about FTFs in near closure or post closure environments. The limitation, however, is that the study's scope was very broad, serving more as review of literature rather than in-depth studies of any individual FTF.

In response to this limitation, the Centre for Social Responsibility in Mining at the University of Queensland funded research to carry out an in-depth study of a mine site in Bolivia that is at the end of its operating life. The research, funded by an early career grant from the Sustainable Minerals Institute, took place in 2011 over a period of ten months and involved a research fellow and a research assistant who are both proficient in Spanish and have previous professional experience in South America. The research fellow specifically selected this mine site because it fulfilled the main criteria for the study's methodology: the selected FTF must function when the parent company is either at the end of the operational phase (near mine closure) or the parent company is no longer influential over the FTF (post mine closure). The advantage of this methodology, from the perspectives of community development specialists and mine closure planners, is that the research was able to document and evaluate a foundation operating at a time when company funds were no longer substantial. Also at this particular juncture management of the foundation required considerable input from the community it was meant to serve which highlights the FTF self-sufficiency and the way it interacted with the affected community.

The study relied on a mixture of desktop and field research. The desktop research examined:

- the historical trajectory of the company and that of the foundation

- the current relationship between the company and the foundation

- the attitudes of the government and community toward the company and the foundation 
- past, current and expected challenges and opportunities

- level and type of community participation

- governance and organisational structure

- effectiveness in program delivery

- operational risks

- funding sources and operating budgets

- staff capacity and numbers

- development philosophy and closure planning.

The desktop research also provided a review of the broader literature on FTFs, mine closure planning, community development and sustainability of civil society financial organisations such as credit cooperatives, credit unions and microfinance entities.

The field research consisted primarily of ten interviews with key foundation and company personnel and community representatives. In preparing for the field research some effort went into the design of the interview discussion points. The discussion points served to guide the unstructured interviews used during the study. The interviews were carried out during a weeklong field visit to Bolivia and served to ascertain if the company was implementing the best practice elements described earlier in the paper. Particular attention was given to the levels of community participation, as this would be used as one indicator of success in FTF program implementation.

\section{Case study context}

The mining company selected for the study was the Bolivian-owned Empresa Inti Raymi S.A. (EMIRSA) and the FTF was the Inti Raymi Foundation. EMIRSA is a gold mining company with rights to the Kori Kollo and Kori Chaca deposits near the historic city of Oruro, $200 \mathrm{~km}$ southeast of the country's capital, La Paz. After nearly three decades of operations the mine is planning to close at the end of 2013.

EMIRSA was established in 1982 as a joint venture between the Bolivian Zealand Mines (50\%) and the Texan Westworld Resources (50\%). In 1988, Battle Gold Mountain Company became EMIRSA's partner, initially acquiring $33 \%$ of the company's shares, which later increased to $88 \%$. Newmont became a majority partner in EMIRSA when it merged with Battle Mountain in January 2001 with Zealand Mines retaining its $12 \%$ interest. In July 2009, Newmont sold its interests in EMIRSA and the company reverted to Bolivian hands (World Bank, 2010b).

At their peak, the Kori Kollo and Kori Chaca deposits were Bolivia's most important gold mines producing over $60 \%$ of the total gold produced in the country. The mines were the first open cut operations using modern extraction and processing technologies. The mines employed around 700 people, the majority of whom were nationals. From inception until 2002, the company paid approximately US\$ 8.2 million per year in salaries and benefits, spent US\$ 18 million annually on local supplier contracts and contributed in excess of US\$ 4 million in taxes (James, 2004).

Mining operations, deposits and the camp are located within the territory of three communities, Chuquiña, La Joya and Iroco, which are all located in the Bolivian arid high plateau (altiplano). These communities were based primarily on subsistence agriculture and livestock production (goats, sheep, alpaca and llama), as well as small-scale cooperative mining (Loayza et al., 2001).

The community of Chuquiña is of Aymara origin and lives according to traditional Andean social customs. In the early 1990s, the main town of Chuquiña was moved to a new location called 'Villa Nueva Chuquiña' due to expected disturbance from mining activities. The process was not without conflicts: the negotiation period was lengthy, some residents resisted relocation and in 1992, they lodged complaints to the Oruro Human Rights Assembly. The conflict was later resolved through an agreement whereby the company 
provided construction materials that were not available in the area, whilst community members provided locally available construction materials and assisted in doing work such as bricklaying. By 1999, 135 houses, market facilities, a hospital, and educational centres had been built, costing the company US\$ 1.8 million (Loayza et al., 2001).

\section{$4 \quad$ EMIRSA and the Inti Raymi Foundation}

EMIRSA was the first mining company in Bolivia to establish a foundation with the purpose of supporting the social and economic development of local communities within its area of influence (Castalia Strategic Advisors, 2008). The Inti Raymi Foundation was established in 1991 and obtained legal status in 1993. The foundation serves 25 communities (including La Joya, Chuquiña and Iroco) located across the provinces of Cercado and Saucarí, in the department of Oruro (Whellams, 2007).

In the early days, and as is common with other mining foundations, community participation in decisionmaking was limited and many projects undertaken by the foundation were destined to improve rural dwellers' capacity to supply the mine with local food and materials. The foundation began to adopt participatory approaches to community development as a result of changes to national legislation in the early 1990s. To support the transition, the foundation sought funding from a number of external sources, including the Inter-American Foundation (IAF), which was instrumental in developing the foundation's participatory framework. By the end of the 1990s the foundation was not only relying on participatory approaches for its own work but had acquired enough capacity to be able to carry out work for others in this regard. For instance, in 2001 the IAF granted US\$21,100 over 14 months to the foundation to undertake an assessment of civil society (especially small-scale producers in the artisan, mining cooperative, small business and rural enterprise sectors) participation rates in Bolivia's National Dialogue which aimed to define a National Poverty Reduction Strategy (IAF, 2001).

In terms of managing the community's expectations, the foundation had a clearly defined methodology for approving projects and only supported activities that promoted local and regional economic development. The foundation also became more independent from the company in terms of being able to manage its own budget. This approach helped the foundation fulfil its programs even when the market price of gold dropped steadily between 1996 and 2001 from US\$ 386 per ounce to a low of US\$ 225 per ounce (Whellams, 2007).

This clarity of purpose and independence had unintended consequences for the foundation. For much of the 1990s and 2000s, EMIRSA's Community Relations (CR) department managed its own community development projects. However, these projects frequently ended up serving, at best, community shortterm needs and at worst, the company's own needs. The messages from the foundation and the CR team to the community were not consistent. Community members played the foundation against the CR team when pleading for funds. According to its long-time director, the foundation is not to be blamed for these inconsistencies. She said that the foundation remained focused on funding only long-term projects and would only consider short-term projects in a small number of cases (B. Alcocer, 14 Oct. 2011, pers. comm). Instead of blaming the CR team a former manager says that these two-faced approach was a reflection of the way the company interacted with the community:

"While the community relations team tried to design all of its projects in such a way that they contribute to sustainable development, these were often used as a way to appease disgruntled communities and avert company-community conflicts that threaten to disrupt the mine's operations" (Whellams, 2007).

Not only did this dualistic response to local residents' demands create the risk of developing a relationship based on what Whellams calls 'mutual extortion' (Whellams, 2007) but also presented the challenge of increasing community dependence on the company's financial resources and of raised community expectations during less economically favourable times (Loayza et al., 2001). 
The foundation's relationship with the government has also been problematic. For instance, the medical centre in Villa Chuquiña was constructed with a combination of funds from the foundation and the State's Social Investment Fund. However, since the centre opened, the foundation has been responsible for the administration of and payment for all services offered. The foundation tried to enter an agreement with the Department of Health that would have require the government to pay for basic health services offered to children and pregnant women, as required under Bolivian law. The government has thus far refused to pay for these services in Villa Chuquiña, arguing that EMIRSA has the resources to be able to pay for them (Whellams, 2007). The government might reconsider this position after the mine closes (B. Alcocer, 14 Oct. 2011, pers. comm.).

The government's lack of interest also affected early closure plans. The company's proposal to transfer the mine's entire infrastructure, including housing, over to the department of Oruro following the mine's closure has had a lukewarm reception. Alternative land uses after closure that the company has suggested to the government include: an industrial park, a university specialising in indigenous studies, a wildlife park, tourist accommodation, or a military base (James, 2004; Whellams, 2007). As of 2011, none of the earlier proposals have been accepted because the government does not want to take on the responsibility of developing projects that might not be feasible (G. Aponte, 13 Oct. 2011, pers. comm.) As a result the latest closure planning objectives are directed at increasing local social capital and strengthening existing safety nets and local economies.

The foundation's relationship with its stakeholders has changed somewhat since Newmont sold its interests in EMIRSA in 2009. The realisation that closure is imminent, increased community participation in the management and implementation of closure projects and the perception that EMIRSA is a local mid-size company with finite resources and not a large multinational, shifted the way stakeholders consider closure risks and opportunities. For instance, foundation personnel also report that demands for compensation are no longer "exorbitant", that community members are more likely to use agreed channels for resolving grievances and that the number of formal general meetings with community members has increased from the occasional yearly meeting to at least two meetings over a year, not counting those carried out by specialised committees (G. Aponte, 13 Oct. 2011, pers. comm.).

Other signs of this shift are evident in the way that community members now opt to move financial resources away from short-term benefits in favour of longer-term development projects. For instance, community members have decided to end company subsidies of their electricity rates and have opted to redirect the windfall towards three recently established community funds. At the operational and administrative level, community members are also more interested in finding out the intricacies of managing community projects and the expertise required to carry these out (G. Aponte, 13 Oct. 2011, pers. comm.).

This shift has not occurred without some effort and changes to the way that both EMIRSA and the foundation interact with the community. The creation of a committee of beneficiaries that includes representation from community members and local level government, has meant that foundation projects now better fulfil community needs and are aligned with regional and national development plans. The company has, after a series of community workshops spread over 12 months, created three community funds (one each for La Joya, Chuquiña and Iroco), whose objectives are to finance a post-closure social safety net and an economic investment program for the region. Each fund has been endowed with US\$ 1 million and will be managed by an independent project management unit. The social safety net comprises both individual as well as collective benefits for all community members living in the area of influence. The individual benefits include government pension top ups, health, life, accident and disability insurance, and payment of funeral expenses. Collective benefits are made up of investment projects selected by the community through participatory budgeting, a process that is widely used in Bolivia at municipal levels of government. The economic investment program prioritises projects that are higher up the value chain, i.e. improving the region's cattle stock through a breeding program. The role of the community funds is also to ensure that there is a smooth transition between the current grant giving and planning role of the foundation, to a more technical and advisory role in the near future when mining 
ceases. All projects implemented by the foundation or any of the three community funds will now be subject to a social committee whose function is to monitor and evaluate social impact and program effectiveness. Both the committee of beneficiaries and the social monitoring committee have representation from broad sections of the community with the former meeting once a month and the latter once a quarter. When compared to pre-2009 levels, the current high levels of community participation in these committees are, so far, the most important measure of success in planning for closure (G. Aponte, 13 Oct. 2011, pers. comm.).

As part of the closure process the company transferred all community relations functions from the company to the foundation, thus saving money for the company and ending the dualistic approach to community development. This does not mean that planning for closure has been an inexpensive process. Since 2009, the company has spent over US\$250,000 in closure planning activities (not including endowing the above mentioned community funds) and a full time team of 1 over 3 years with inputs from specialist consultants (G. Aponte, 13 Oct. 2011, pers. comm.).

The improvement in relations has also been influenced by outside factors such as the high price of gold and the election to government of Evo Morales, Bolivia's first Indigenous president. The price of gold has allowed the company to carry out closure according to plan, and Morales' political discourse and changes to the mining code have emboldened Indigenous communities to become more involved in running their own affairs.

The improvement in relations between EMIRSA, the foundation and the affected communities however, should not be attributed solely to recent changes in the political life of the country nor the high price of gold in international markets. Many of the external factors that have influenced the foundation and the company are not recent. For instance, the Law of Popular Participation, the Law of Decentralization and the Law of Social Security were introduced in the early 1980s and conditioned the way EMIRSA, the foundation and the surrounding communities relate to each other (EIR, 2002).

\section{Conclusions}

Like many other mines around the world EMIRSA has experienced problems with its surrounding communities and has unintentionally created problems for its own foundation. It seems, however, that in recent years and with a changed structure, the foundation is achieving the mine objective of organising the community to be prepared for mine closure. The most important indicator of this achievement is that the communities of La Joya, Chuquiña and Iroco are more pro-active in the process of closure planning now than they were three years ago. Increased participation will, ideally, move them from being governed by company prerogatives to being governed by their own vision of economic and social development. Furthermore, in the process of closure planning these communities are realising the limitations, both financial and institutional, that they will face once mining is no longer the main economic activity in the area. It is also evident from the research that it took a lot of effort, strategic planning and resources from the company and the foundation to get the community to this level of awareness and participation. External factors have impacted positively on the way that the mine operator and the community are planning for closure but these same factors could have had a completely different outcome had there been less engagement between stakeholders. Subsequent research in these communities after the mine closes will reveal if these communities manage their funds efficiently and achieve the goals they set for themselves. So far it seems that the company and the foundation are following many best practice elements when it comes to planning for closure and the affected communities are responding well to the process.

\section{Acknowledgement}

This research was possible with a grant from the Sustainable Minerals Institute at the University of Queensland. The author would like to thank Ms Nina Collins, researcher at the Centre for Social Responsibility in Mining for all of her assistance during this study. The author would also like to thank 
Mr Guillermo Aponte, Pedro Velasco and Juan Cristobal Urioste at EMIRSA for their support during field research and all those at the Fundación Inti Raymi, specially Ms Beatriz Alcocer and Sergio Claros, for their generosity in providing valuable information for this study.

\section{References}

Banks, G. (2003) Landowner equity in Papua New Guinea's minerals sector: Review and policy issues, Natural Resources Forum 27 , pp. 223-234.

Barclay, M.A. (2010) Implementing policy frameworks for sustainable development in the Australian mining industry: maintaining a social license to operate in turbulent economic times, in Proceedings 16th Annual International Sustainable Development Research Conference, Hong Kong, 30 May-1 June, 2010, Available at: http://www.kadinst.hku.hk/sdconf10/Papers_PDF/ p112.pdf.

Barney, I. (2003) Business, community development and sustainable livelihoods approaches, Community Development Journal, Vol. 38, Issue 3, pp. 255-265.

Castalia Strategic Advisors (2008) Urban Infrastructure for Southern Mongolia - Background Study: Report to the World Bank, viewed 09/05/2011, http://siteresources.worldbank.org/MONGOLIAEXTN/Resources/Urban_Infrastructure_Southern_ Mongolia.pdf.

CSRM (2009) Centre for Social Responsibility in Mining. An Overview: Community Development Funds, Report prepared for Lihir Gold Limited, The University of Queensland, Brisbane.

CSRM (2005) Centre for Social Responsibility in Mining. Report on the evaluation of the BHP Billiton Mitsubishi Alliance Community Partnerships Program, The University of Queensland, Brisbane.

Davy, A. (2000) Emerging Lessons for Tri-sector Partnerships: A Review of Four Case-studies, Business Partners for Development: Natural Resources Cluster, February 2000, http://www.odi.org.uk/work/projects/98-02-bpd-natural-resources-cluster/ media/pdf/working/work3.pdf.

DRET (2009) Department of Resources Energy and Tourism. Mine Closure and Completion.

EIR (2002) The Extractive Industries Review. Latin America and Caribbean Regional Workshop: Testimonials and Consultation Report, Rio de Janeiro, Brazil, 15-19 April 2002.

Esteves, A.M. and Vanclay, F. (2009) Social development needs analysis as a tool for SIA to guide corporate-community investment: Applications in the minerals industry, Environmental Impact Assessment Review, Vol. 29, pp. 137-145.

Finucane, S.J. and Santini, T.C. (2010) Corporate (ir)responsibility: what is it really worth when times are tough?, in Proceedings Fifth International Conference on Mine Closure (Mine Closure 2010), A.B. Fourie, M. Tibbett and J. Wiertz (eds) 23-26 November 2010, Viña del Mar, Chile, Australian Centre for Geomechanics, Perth, pp. 3-15.

Hamann, R., Acutt, N. and Carter, A. (2001) Corporate Foundations and Trisector Partnerships, Business Partners for Development: Natural Resources Cluster, http://www.odi.org.uk/work/projects/98-02-bpd-natural-resources-cluster/media/pdf/ working/work11.pdf.

Haney, M. and Shkaratan, M. (2003) Mine closure and its impact on the community: five years after mine closure in Romania, Russia and Ukraine, The World Bank, Europe and Central Asia Region, Infrastructure and Energy Services Department, June 2003, http://www-wds.worldbank.org/external/default/WDSContentServer/IW3P/IB/2003/07/26/000094946_ 03071704241696 /Rendered/PDF/multiOpage.pdf.

IAF (2001) Inter-American Foundation. Grants - Awards by Year: Bolivia 2001, viewed 20/05/2011, http://www.iaf.gov/grants/ awards_year_text_en.asp?country_id=3\&gr_year=2001.

ICMM (2010) International Council on Mining and Metals. Mining: Partnerships for Development: Using resource endowments to foster sustainable development, Mapping in-country partnerships, London.

ICMM (2006) International Council on Mining and Metals. Integrated Closure Planning - summary of the scoping study, London, viewed 24/05/2011, http://www.icmm.com/document/220.

ICMM (2005) International Council on Mining and Metals. Community Development Toolkit viewed 24/05/2011, http://www.icmm.com/document/2.

IFC (2010) International Finance Corporation. Strategic Community Investment: A Good Practice Handbook for Companies Doing Business in Emerging Markets, viewed 19/05/2011, http://www.ifc.org/ifcext/sustainability.nsf/AttachmentsByTitle /p_StrategicCommunitylnvestment_full/\$FILE/12014complete-web.pdf.

IIED and WBCSD (2002) International Institute for Environment and Development; and World Business Council for Sustainable Development. Breaking New Ground: Mining, Minerals and Sustainable Development: The Report of the MMSD Project, London.

Jackson, R.T. (2002) Capacity building in Papua New Guinea for community maintenance during and after mine closure, Report commissioned by the Mining, Minerals and Sustainable Development (MMSD) project of the International Institute for Environment and Development (IIED).

James, K. (2004) The Lifecycle of CSR Programs, Inti Raymi Gold Mine, Inter-American Foundation, http://www.iaf.gov/grants/ downloads/intiraymi_eng.pdf.pdf.

Laurence, D. (2006) Optimisation of the mine closure process, Journal of Cleaner Production, Vol. 14, No. 3-4, pp. $285-98$.

Loayza, F., Franco, I., Quezada, F. and Alvarado, M. (2001) Bolivia: Turning Gold into Human Capital, in Large mines and the community: socioeconomic and environmental effects in Latin America, Canada, and Spain, F.R.G. McMahon (ed), International Development Research Centre and The World Bank. 
Lowe, J.S. (2004) Community Foundations: What Do They Offer Community Development?, Journal of Urban Affairs, Vol. 26, No. 2, pp. 221-40.

McGuire, G.M. (2003) Managing mine closure risks in developing communities - a case study, Kelian equatorial mining, Indonesia, in Proceedings Effective Risk Management for Mining Project Optimisation, Mining Risk Management Conference 2003, pp. 385-93.

Rose, J.E. and Morgan, H.L. (2010) Tea and cake: talking with communities about life after mining, in Proceedings Fifth International Conference on Mine Closure (Mine Closure 2010), A.B. Fourie, M. Tibbett and J. Wiertz (eds), 23-26 November 2010, Viña del Mar, Chile, Australian Centre for Geomechanics, Perth, pp. 159-166.

Sera, Y. and Reynolds, D. (2008) World Bank Community Foundation Initiative Evaluation Report, http://www.usig.org/PDFs/ CFlevaluation.pdf.

Stacey, J., Naude, A., Hermanus, M. and Frankel, P. (2010) The socio-economic aspects of mine closure and sustainable development: literature overview and lessons for the socio-economic aspects of closure-Report 1, Journal of the South African Institute of Mining and Metallurgy, Vol. 110, No. 7, pp. 379-94.

Warhurst, A. (2002) Corporate citizenship and corporate social investment: drivers of tri-sector partnerships, Journal of Corporate Citizenship, Vol. 1, No. 1, pp. 57-73.

Warhurst, A., Macfarlane, M. and Wood, G. (2000) Issues in the Management of the Socioeconomic Impacts of Mine-closure: A Review of Challenges and Constraints, in Environmental Policy in Mining: Corporate Strategy and Planning for Closure, A. Warhurst and L. Noronha (eds), Lewis Publishers, Boca Raton, pp. 81-99.

Whellams, M. (2007) The Role of CSR in Development: A Case Study Involving the Mining Industry in South America, Masters of International Development Studies thesis, Saint Mary's University, viewed 9/05/2011, http://www.whellams.com/ downloads/MWThesis.pdf.

World Bank (2010a) Examining Foundations, Trusts and Funds (FTFs) in the Mining Sector, World Bank.

World Bank (2010b) Mining Foundations, Trusts and Funds: A Sourcebook, World Bank.

World Bank and International Finance Corporation (2002) It's Not Over When It's Over: Mine Closure Around the World, Washington D.C.

Yakovleva, N. and Alabaster, T. (2004) Tri-sector partnership for community development in mining: a case study of the SAPI Foundation and Target Fund in the Republic of Sakha (Yakutia), Resources Policy, Vol. 29, No. 3-4, pp. 83-98. 